\title{
Penggunaan Ekstrak Pelepah Pisang Ambon sebagai Sanitizer Kerabang terhadap Daya Tetas Telur Itik Lokal
}

\author{
The Use of Ambon Banana Pseudostem Extract as Eggshell Sanitizer on Local Duck Eggs Hatchability \\ F. K. Ramadhan ${ }^{1}$, Rukmiasih $^{1}$, \& R. Afnan ${ }^{1}$ \\ ${ }^{1}$ Departemen Ilmu Produksi dan Teknologi Peternakan, Fakultas Peternakan, IPB \\ Jalan Agatis, Kampus IPB Dramaga, Bogor 16680, Indonesia \\ Email koresponding author: fahmikr51@gmail.com
}

\begin{abstract}
The use of $\mathrm{KMnO}_{4}$ and formalin $40 \%$ for fumigation of hatching machine and hatching eggs has potential hazards to safety and health. Some previous studies have shown that banana pseudostem extract can act as an antimicrobial. This study aimed to examine the use of ambon banana pseudostem extract (Musa paradisiaca var. Sapientum) with concentrations of $10 \%, 20 \%$, and $30 \%$ as eggshell sanitizer to the hatchability of local duck eggs. The results showed eggs hatchability that use of $10 \%$ banana pseudostem extract still lower than eggs hatchability that use fumigation. The higher concentration of banana pseudostem extract can reduce the hatchability. Therefore, it is necessary to try experiment use banana peseudostem extract with concentration lower than $10 \%$.
\end{abstract}

Keywords: fumigation, hatchability, local duck, banana pseudostem extract

\begin{abstract}
ABSTRAK
Penggunaan $\mathrm{KMnO}_{4}$ dan formalin $40 \%$ untuk fumigasi mesin tetas dan telur tetas memiliki potensi bahaya untuk keamanan dan kesehatan. Beberapa penelitian sebelumnya telah menunjukkan bahwa ekstrak pelepah pisang ambon memiliki potensi sebagai antimikroba. Penelitian ini bertujuan untuk mengkaji penggunaan ekstrak pelepah pisang ambon (Musa paradisiaca var. Sapientum) dengan konsentrasi $10 \%, 20 \%$, dan $30 \%$ sebagai sanitizer terhadap daya tetas telur itik lokal. Hasil penelitian menunjukkan daya tetas telur yang disanitasi dengan ekstrak pelepah pisang ambon konsentrasi $\mathbf{1 0 \%}$ masih lebih rendah daripada telur yang difumigasi. Semakin tinggi konsentrasi ekstrak pelepah pisang ambon dapat menurunkan daya tetas. Untuk itu, perlu dilakukan penelitian lebih lanjut menggunakan konsentrasi ekstrak pelepah pisang dengan konsentrasi yang lebih rendah dari $10 \%$.
\end{abstract}

Kata kunci: daya tetas, fumigasi, ektrak pelepah pisang, itik lokal

\section{PENDAHULUAN}

Peningkatan populasi itik dari tahun ke tahun lebih rendah $(13.72 \%$ dalam 5 tahun terakhir) dibandingkan dengan populasi ayam ras $(26.35 \%$ dalam 5 tahun terakhir) (Ditjen PKH 2017). Salah satu sebabnya adalah daya tetas telur itik masih rendah.Rendahnya daya tetas disebabkan diantaranya oleh kontaminasi mikroba akibat telur yang kotor. Menurut Aripin (2013), kebersihan telur merupakan bagian terpenting dalam proses penetasan di dalam mesin tetas. Telur yang kotor memungkinkan banyaknya kontaminasi bakteri yang dapat menyebabkan kegagalan dalam proses penetasan. Proses sanitasi merupakan salah satu upaya yang dilakukan untuk mematikan bakteri yang menempel pada telur. Sanitasi pada telur tetas yang sering dilakukan adalah fumigasi menggunakan $\mathrm{KMnO}_{4}$ dan formalin $40 \%$. Namun penggunaan $\mathrm{KMnO}_{4}$ dan formalin memiliki potensi bahaya. Menurut Murtidjo (2005), formalin mempunyai sifat karsinogenik yang dapat mematikan embrio dan membahayakan kesehatan operator. Konsentrasi formalin 0.1-5.0 ppm dapat menyebabkan iritasi pada hidung dan tenggorokan (BPOM 2008). Menurut Alkhakim et al. (2016), desinfeksi menggunakan bahan kimia dengan konsentrasi rendah tidak dapat membunuh bakteri patogen pada telur, sedangkan pada konsentrasi yang tinggi dapat membunuh embrio dalam telur. 
Pisang (Musa paradisiaca) merupakan tanaman yang banyak dijumpai di Indonesia. Produksinya mencapai 8000 000 ton pada tahun 2015 (Kementan 2016). Pemanfaatannya tidak hanya sebagai bahan pangan, tetapi juga sebagai bahan pengobatan. Beberapa penelitian telah dilakukan untuk mengetahui aktivitas antimikroba dari pohon pisang, mulai dari kulit sampai dengan batangnya. Penelitian Onyema et al. (2016) menunjukkan ekstrak pelepah (pseudostem) pisang mampu melawan pertumbuhan bakteri. Hasil penelitian Nur et al. (2012) membuktikan penggunaan getah murni pelepah pisang ambon Musa paradisiaca var. Sapientumpada konsentrasi 15\% menunjukkan aktivitas antibakteri paling tinggi karena mampu menghambat pertumbuhan bakteri Staphylococcus aureus, Pseudomonas aeuroginosa dan Escherichia coli dengan rata-rata diameter masing-masing zona hambatan 22.5, 10.5, dan 10.25 mm.Menurut Davis dan Stout (1971) dalam Mahmudah dan Atun (2017) klasifikasi respon hambatan pertumbuhan bakteri yang dilihat berdasarkan diameter zona bening terdiri atas 4 kelompok yaitu respon lemah (diameter $\leq 5$ $\mathrm{mm}$ ), sedang (diameter 5-10 mm), kuat (diameter 10-20 $\mathrm{mm}$ ), dan sangat kuat (diameter $\geq 20 \mathrm{~mm}$ ).

Pelepah pisang mengandung beberapa fitokimia. Penelitian Fitrianingrum (2015) menunjukkan pelepah pisang ambon memiliki kandungan fitokimia seperti flavonoid, alkaloid, triterpenoid, fenolik, saponin, tanin, steroid, dan glikosida. Zat-zat aktif seperti flavonoid, saponin, tanin, dan alkaloid yang terkandung dalam berbagai tanaman memiliki efek yang signifikan dalam menghambat pertumbuhan bakteri (Zukhri dan Hidayati 2017). Penelitian ini dirancang memanfaatkan ekstrak pelepah pisang ambon sebagai bahan untuk mendesinfeksi telur itik dengan harapan daya tetas telur itik yang diperoleh sama dengan fumigasi menggunakan $\mathrm{KMnO}_{4}$ dan Formalin $40 \%$.

\section{MATERI DAN METODE}

\section{Waktu dan Tempat Penelitian}

Penelitian ini dilaksanakan di Laboratorium Penetasan, Divisi IPT Unggas, Departemen Ilmu Produksi dan Teknologi Peternakan, Fakultas Peternakan IPB.

\section{Materi Penelitian}

Materi yang digunakan dalam penelitian ini adalah 500 butir telur itik alabio yang dihasilkan oleh induk itik berumur 60 minggu dari peternakan di daerah Gunung Sindur, Parung, Bogor, Jawa Barat. Induk itik dipelihara dalam 1 flok dengan sistem pemeliharaan intensif dan perbandingan populasi jantan dan betina 1:5. Bahan lain yang digunakan adalah kalium permanganat $\left(\mathrm{KMnO}_{4}\right)$, formalin $40 \%$, pelepah pisang ambon, air hangat $\left( \pm 38^{\circ} \mathrm{C}\right)$, detergen, dan desinfektan.

\section{Prosedur Penelitian \\ Persiapan Mesin Tetas dan Peralatannya}

Peralatan yang ada di dalam mesin tetas (rak telur dan bak air) dikeluarkan, dibersihkan dari debu-debu yang menempel, dicuci dengan air bersih dan detergen, lalu didesinfeksi dengan desinfektan Destan $(15 \mathrm{~mL}$ untuk $10 \mathrm{~L}$ air) serta dikeringkan.Termometer dan mesin tetas dilap dengan kain basah yang mengandung desinfektan dan dikeringkan. Bagian dalam mesin tetas dibersihkan dari debu dan kotoran sisa penetasan sebelumnya dengan cara kering. Kemudian dibersihkan dengan lap basah yang mengandung detergen, lalu dengan lap basah yang mengandung desinfektan dengan memperhatikan peralatan listrik agar tidak terjadi korsleting.

Setelah semua peralatan dan mesin tetas kering, peralatan dimasukkan kembali ke dalam mesin tetas dan semua lubang ventilasi ditutup. Selanjutnya, mesin tetas dan peralatannya difumigasi dengan dosis 3 kali kekuatan (60 $\mathrm{g} \mathrm{KMnO}_{4}$ dan $120 \mathrm{~mL}$ formalin $40 \%$ untuk setiap $2.83 \mathrm{~m}^{3}$, selama minimal 30 menit). Setelah itu, suhu dan kelembaban mesin tetas diatur $37-38{ }^{\circ} \mathrm{C}$ dan $60 \%-70 \%$ pada 1-25 hari, sedangkan pada hari ke 26-28 (menetas) diatur $36.5-37.5^{\circ} \mathrm{C}$ dan $70 \%-80 \%$.

\section{Pembuatan Ekstrak Pelepah Pisang}

Pelepah pisang diambil dari pohon pisang yang baru saja dipanen buahnya. Pelepah pisang dicuci terlebih dahulu, kemudian dilakukan pencacahan agar memudahkan proses penghancuran. Setelah dicuci dan dicacah, potongan pelepah pisang kemudian dijemur di bawah sinar matahari selama 3 hari sampai kering. Setelah kering, kemudian dicampur dengan air dan digiling menggunakan blender selama 5 menit.

Ekstraksi dilakukan menggunakan metode infusa yaitu campuran dipanaskan selama 15 menit pada suhu $90 \mathrm{oC}$ dan diaduk sesekali (BPOM 2010). Perbandingan pelepah pisang dan air untuk membuat ekstrak disesuaikan dengan dosis yang diinginkan $(10 \%, 20 \%, 30 \%)$ menggunakan bobot per volume. Setelah dipanaskan, pelepah pisang disaring untuk mendapatkan ekstraknya.

\section{Persiapan Telur Tetas}

Telur diseleksi sesuai dengan kriteria telur tetas yaitu tidak retak, bentuk normal, bobotnya tidak terlalu besar dan tidak terlalu kecil (65-75 g). Telur yang digunakan berumur 3 hari sebanyak 500 butir telur. Sebelum diberi perlakuan, semua telur dicuci dengan air hangat $\left( \pm 38{ }^{\circ} \mathrm{C}\right)$ untuk membersihkan kotoran yang menempel di kerabang telur.

Telur dibagi menjadi 5 kelompok perlakuan yaitu P0 (tanpa fumigasi, tanpa sanitasi dengan ekstrak pelepah pisang ambon), P1 (difumigasi menggunakan formalin $40 \%$ dan $\mathrm{KMnO}_{4}$ dengan dosis 2 kali kekuatan selama 15 menit), P2 (disanitasi dengan ekstrak pelepah pisang 10\%), P3 (disanitasi dengan ekstrak pelepah pisang 20\%), dan P4 (disanitasi dengan ekstrak pelepah pisang 30\%). Telur P2, P3, dan P4 disanitasi dengan cara merendam telur di ekstrak pelepah pisang di masing-masing konsentrasi. Perendaman dilakukan selama 5 menit (Beleh 2008), kemudian telur ditiriskan.

\section{Proses Penetasan}

Proses penetasan dilakukan pada 4 unit mesin tetas (sebagai ulangan/blok). Selama 25 hari pertama suhu dan kelembaban diatur pada $37-38{ }^{\circ} \mathrm{C}$ dan $60 \%-70 \%$, dan 3 hari terakhir suhu dan kelembaban diatur $36.5-37.5{ }^{\circ} \mathrm{C}$ dan $70 \%-80 \%$. Pemutaran telur mulai hari ketiga sampai 25 hari dilakukan sebanyak 3 kali dalam sehari dengan 
rentang waktu 6 jam yaitu pukul 07.00, 13.00, dan 19.00 WIB. Ventilasi dibuka1/3 bagian mulai umur 3 hari, terus diperlebar setiap hari hingga semua ventilasi terbuka pada umur 7 hari.

Suhu dan kelembaban mesin tetas dicatat setiap hari sebanyak 3 kali: pagi, siang, dan malam. Candling telur dilakukan 2 kali yaitu pada hari ke-7 dan hari ke25. Candling hari ke-7 dilakukan untuk menentukan telur infertil, telur mati dan telur fertil hidup. Telur mati dan telur infertil dikeluarkan dari mesin tetas. Candling kedua pada hari ke-25 dilakukan untuk mengeluarkan embrio yang mati dan menghitung bobot telur.

\section{Pemanenan DOD}

Pemanenan day old duck (DOD) dilakukan setelah telur menetas. Jumlah DOD dan telur yang tidak menetas kemudian dicatat dan dianalisis datanya. Telur yang tidak menetas dipecah, dilakukan pengamatan untuk mengetahui umur kematian dan penyebab kematian embrio.

\section{Analisis Data}

Penelitian ini menggunakan Rancangan Acak Kelompok (RAK) yang terdiri atas 5 perlakuan yaitu:

1. Tanpa fumigasi dan tanpa sanitasi dengan ekstrak pelepah pisang ambon (P0);

2. Difumigasi menggunakan fromalin $40 \%$ dan $\mathrm{KMnO}_{4}$ dengan dosis 2 kekuatan selama 15 menit, tanpa sanitasi ekstrak pelepah pisang ambon (P1);

3. Disanitasi dengan ekstrak pelepah pisang ambon $10 \%$ (P2);

4. Disanitasi dengan ekstrak pelepah pisang ambon $20 \%$ (P3); dan

5. Disanitasi dengan ekstrak pelepah pisang ambon $30 \%$ (P4).

Metode sanitasi yang digunakan adalah perendaman. Perendaman telur dalam larutan ektrak pelepah pisang ambon dilakukan selama 5 menit (Beleh 2008), kemudian telur ditiriskan. Setiap perlakuan terdiri atas 4 blok/ulangan dan setiap ulangan terdiri atas 25 butir telur.

Hasil penelitian, berupa data performa penetasan (fertilitas, susut bobot, dan daya tetas) dianalisis ragam dan untuk mengetahui perbedaan rataan antar perlakuan dilakukan uji Duncan. Data susut bobot antara telur yang menetas dan tidak menetas, selain dianalisis ragam, juga dianalisis dengan uji-t. Model Rancangan Acak Kelompok menurut Steel dan Torrie (1995) sebagai berikut:

$$
\mathrm{Yij}=\mu+\tau i+\beta \mathrm{j}+\varepsilon \mathrm{ij}
$$

\section{Keterangan :}

Yij = pengamatan perlakuan ke-i pada ulangan ke-j;

$\mu \quad=$ rata-rata umum peubah yang diamati;

$\tau \mathrm{i}=$ pengaruh perlakuan sanitasi ke- $\mathrm{i}(\mathrm{i}=1,2, \ldots, 5)$;

$\beta \mathrm{j}=$ pengaruh kelompok ke- $\mathrm{j}(\mathrm{j}=1,2,3,4)$; dan

cij = galat perlakuan ke-i dan kelompok ke-j.

\section{Peubah yang Diamati}

Peubah yang diamati dalam penelitian ini antara lain:

1. Fertilitas

Fertilitas telur diukur dengan cara menghitung persentase jumlah telur fertil dengan jumlah telur yang dimasukan ke dalam mesin tetas $\mathrm{x} 100 \%$. Pemeriksaan fertilitas dilakukan pada hari ke-7. Telur yang fertil memiliki ciri-ciri berkembangnya germinal disc, terlihatnya detak jantung, dan terlihatnya pembuluh darah;

2. Susut bobot telur

Susut bobot telur diukur dengan cara menghitung selisih bobot telur pada saat awal sebelum dimasukan ke dalam mesin tetas dan saat telur telah berumur 25 hari di dalam mesin tetas kemudian dibagi bobot telur awal lalu dikali $100 \%$;

3. Daya tetas

Daya tetas diukur dengan cara menghitung jumlah telur yang menetas dibagi jumlah telur fertil lalu dikali 100\%;

4. Umur kematian embrio dan telur yang terkontaminasi

Umur kematian embrio diketahui dengan cara memecahkan kerabang telur yang gagal menetas dan meletakannya di cawan petri. Embrio yang mati kemudian diamati untuk ditentukan umur kematiannya ( $<8$ hari, 8-25 hari, dan $>25$ hari) dan penyebab kematiannya. Telur yang terkontaminasi memiliki ciriciri explode, berbau busuk, dan isi telur menggumpal sampai berwarna hitam.

\section{HASIL DAN PEMBAHASAN}

\section{Suhu dan Kelembaban Mesin Tetas}

Suhu dan kelembaban mesin tetas selama penelitian disajikan pada Tabel 1. Suhu dan kelembaban selama periode penetasan mengalami fluktuasi. Suhu dan kelembaban mesin tetas berperan penting pada penetasan karena dapat mempengaruhi perkembangan embrio.

\begin{tabular}{ccccc}
\multicolumn{6}{l}{ Tabel 1. Suhu dan kelembaban mesin tetas } \\
\hline \multirow{2}{*}{ Mesin } & \multicolumn{2}{c}{ Suhu $\left({ }^{\circ} \mathrm{C}\right)$} & \multicolumn{2}{c}{ Kelembaban $(\%)$} \\
\cline { 2 - 5 } & Setter & Hatcher & Setter & Hatcher \\
\hline 1 & $37.87 \pm 0.27$ & $37.06 \pm 0.40$ & $66.33 \pm 5.60$ & $70.33 \pm 1.95$ \\
2 & $37.86 \pm 0.39$ & $37.21 \pm 0.26$ & $68.82 \pm 6.10$ & $76.27 \pm 0.35$ \\
3 & $37.84 \pm 0.37$ & $36.98 \pm 0.51$ & $60.53 \pm 4.92$ & $66.17 \pm 1.95$ \\
4 & $37.81 \pm 0.35$ & $37.03 \pm 0.36$ & $65.85 \pm 4.04$ & $72.67 \pm 1.69$ \\
\hline
\end{tabular}

Tabel 1 menunjukkan suhu pada periode setting sudah sesuai dengan yang disarankanoleh Mulyantini (2010) yaitu $37.2-38.2^{\circ} \mathrm{C}$ pada periode setting dan $37-37.5^{\circ} \mathrm{C}$ pada periode hatching. Suhu yang terlalu tinggi dapat menyebabkan waktu menetas yang lebih singkat, penguapan cairan lebih tinggi, DOD yang dihasilkan kering, dan kematian embrio. Pada periode hatcher, suhu mesin tetas diturunkan dengan tujuan untuk mencegah terjadinya cekaman panas di mesin tetas yang dapat menyebabkan kematian embrio. Hal ini karena pada periode ini embrio sudah dapat menghasilkan panas sendiri akibat meningkatnya metabolisme sejalan dengan bertambahnya umur.

Kelembaban mesin tetas pada periode settingselama penelitian sudah sesuai, sedangkan kelembaban mesin tetas pada periode hatching lebih rendah dari aplikasi Hanoun dan Mossad (2008) yang menaikan sampai dengan 80\%. Kelembaban udara berfungsi untuk mengurangi atau menjaga cairan dalam telur dan merapuhkan kerabang telur 
(Ningtyas 2013).Kelembaban yang tinggi terutama pada hari ke-1-25 menurut Ahyodi et al. (2014) akan menyebabkan pertukaran oksigen dan karbondioksida serta penguapan air akibat perkembangan embrio berkurang.

Kelembaban mesin tetas yang terlalu rendah dapat mempercepat penguapan cairan dari telur yang mengakibatkan embrio akan kekeringan. Pada periode hatcher, kelembaban dinaikan dengan tujuan untuk merapuhkan kerabang telur. Kerabang telur yang terlalu keras dapatmenyebabkan itik sulit menetas dan akhirnya mati.

\section{Bobot Telur}

Bobot telur merupakan salah satu kriteria yang harus diperhatikan dalam penetasan. Bobot telur salah satunya berpengaruh terhadap keseragaman bobot DOD. Bobot telur yang digunakan dalam penelitian ini disajikan pada Tabel 2. Tabel 2 menunjukkan bobot telur itik alabio dalam penelitian ini seragam (koefisien keragaman $<10 \%$ ).

Bobot telur yang seragam dalam penelitian ini dikarenakan telur berasal dari induk itik albio yang dipelihara dalam 1 flok dengan umur dan manajemen pemeliharaan yang sama. Telur itik yang digunakan berasal dari induk berumur 60 minggu yang dipelihara secara intensif. Bobot telur yang digunakan dalam penelitian ini masih sesuai dengan yang disarankan Dewanti et al. (2014) bahwa bobot telur itik lokal yang ideal untuk ditetaskan berkisar 53-76 g. Berdasarkan SNI (2009), bobot minimal telur tetas itik alabio adalah $58 \mathrm{~g}$. Semakin tua umur induk, bobot telur yang dihasilkansemakin besar (Diniati 2013). Bobot telur akan berpengaruh terhadap bobot tetas. Semakin besar bobot telur makabobot DOD yang dihasilkan juga semakin besar (Dewanti et al. 2014).

\section{Fertilitas Telur}

Fertilitas merupakan telur tetas yang terdapat perkembangan embrio di dalamnya. Hari ke-7 dipilih karena pada periode tersebut diharapkan sudah terlihat perkembangan pembuluh darah sehingga memudahkan dalam pemeriksaan. Fertilitas telur itik alabio yang digunakan dalam penelitian ini ditunjukkan pada Tabel 3.

Telur itik yang digunakan dalam penelitian ini berasal dari induk berumur 60 minggu yang dipelihara secara intensif dengan perbandingan jantan dan betina 1:5. Hasil uji statistik menunjukkan tidak adanya pengaruh perlakuan terhadap fertilitas telur. Fertilitas telur itik

Tabel 2. Bobot telur itik alabio

\begin{tabular}{|c|c|c|c|c|c|}
\hline \multirow[t]{3}{*}{ Mesin } & \multicolumn{5}{|c|}{ Rataan $\pm \mathrm{sb}(\mathrm{KK})$} \\
\hline & P0 & P1 & $\mathrm{P} 2$ & P3 & P4 \\
\hline & \multicolumn{5}{|c|}{ Gram } \\
\hline \multirow[t]{2}{*}{1} & $66.44 \pm 4.56$ & $66.84 \pm 4.22$ & $67.92 \pm 3.85$ & $67.76 \pm 4.68$ & $66.60 \pm 3.92$ \\
\hline & $-6,86$ & $-6,31$ & $-5,67$ & $-6,91$ & $-5,88$ \\
\hline \multirow[t]{2}{*}{2} & $67.32 \pm 5.21$ & $66.80 \pm 3.75$ & $67.32 \pm 3.01$ & $68.00 \pm 5.26$ & $67.08 \pm 5.92$ \\
\hline & $-7,74$ & $-5,62$ & $-4,47$ & $-7,74$ & $-8,83$ \\
\hline \multirow[t]{2}{*}{3} & $65.28 \pm 3.93$ & $63.56 \pm 3.04$ & $66.96 \pm 4.37$ & $67.80 \pm 5.80$ & $67.72 \pm 5.90$ \\
\hline & $-6,02$ & $-4,79$ & $-6,53$ & $-8,56$ & $-8,71$ \\
\hline \multirow[t]{2}{*}{4} & $67.20 \pm 4.69$ & $66.24 \pm 4.59$ & $64.40 \pm 4.52$ & $68.00 \pm 4.33$ & $67.28 \pm 6.57$ \\
\hline & $-6,98$ & $-6,92$ & $-7,02$ & $-6,37$ & $-9,77$ \\
\hline Rataan $\pm \mathrm{sb}$ & $66.56 \pm 0.94$ & $65.86 \pm 1.56$ & $66.65 \pm 1.55$ & $67.89 \pm 0.13$ & $67.17 \pm 0.46$ \\
\hline \multirow{2}{*}{\multicolumn{6}{|c|}{$\begin{array}{l}\text { Keterangan: } \\
\text { P0 = Tanpa fumigasi dan tanpa sanitasi ekstrak pelepah pisang ambon; }\end{array}$}} \\
\hline & & & & & \\
\hline \multicolumn{6}{|c|}{ P1 = Difumigasi menggunakan formalin $40 \%$ dan $\mathrm{KMnO}_{4}$ dengan dua kali kekuatan (15 menit); } \\
\hline \multicolumn{6}{|c|}{ P2 = Disanitasi dengan ekstrak pelepah pisang ambon konsentrasi $10 \%$} \\
\hline \multicolumn{6}{|c|}{ P3 = Disanitasi dengan ekstrak pelepah pisang ambon konsentrasi $20 \%$; dan } \\
\hline P4 = Disan & strak pelep & nbon konser & & & \\
\hline
\end{tabular}

Tabel 3. Fertilitas telur itik alabio

\begin{tabular}{cccccc}
\hline Mesin & \multicolumn{5}{c}{ Fertilitas (\%) } \\
\cline { 2 - 6 } & P0 & P1 & P2 & P3 & P4 \\
\hline 1 & 88 & 76 & 76 & 72 & 68 \\
2 & 72 & 68 & 64 & 80 & 96 \\
3 & 84 & 76 & 68 & 68 & 80 \\
4 & 64 & 88 & 88 & 68 & 80 \\
\hline Rataan $\pm \mathrm{sb}$ & $77.00 \pm 11.02$ & $77.00 \pm 8.25$ & $74.00 \pm 10.58$ & $72.00 \pm 5.66$ & $81.00 \pm 11.49$ \\
\hline
\end{tabular}


dipengaruhi diantaranya oleh rasio jantan dan betina, umur induk, pakan, umur telur (Sari et al. 2011), kualitas organ reproduksi betina, dan kualitas sperma (Dewanti et al. 2014). Persentase fertilitas yang beragam pada penelitian ini diduga karena perbedaan kualitas sperma dan kondisi organ reproduksi betina.

Tabel 3 menunjukkan fertilitas telur pada penelitian ini lebih rendah dibandingkan dengan fertilitas telur itik alabio pada penelitian Darmawati (2013) yaitu sebesar 95.67\%. Perbedaan fertilitas ini diduga disebabkan perbedaan umur induk. Penelitian Darmawati (2013) menggunakan telur yang berasal dari induk alabio umur 28 minggu, sedangkan telur yang digunakan dalam penelitian ini berasal dari itik alabio berumur 60 minggu. Umur induk yang semakin tua menyebabkan kualitas organ reproduksinya berkurang sehingga menghasilkan fertilitas yang rendah.

\section{Susut Bobot Telur}

Susut bobot telur merupakan salah satu parameter yang digunakan untuk mengevaluasi proses penetasan. Selama proses inkubasi, terjadi proses penguapan air dari dalam telur yang menyebabkan penyusutan bobot telur. Susut bobot telur pada penelitian ini disajikan dalam Tabel 4.

Tabel 4 menunjukkan susut bobot telur dalam penelitian ini tidak seragam (koefisien keragaman $>10 \%$ ). Susut bobot telur tidak seragam karena setiap telur memiliki karakteristik yang berbeda. Hasil data menunjukkan rataan susut bobot telur yang menetas lebih tinggi dibandingkan dengan yang tidak menetas. Analisis statistik (uji-t) menunjukkan susut bobot telur yang menetas nyata lebih tinggi dari telur yang tidak menetas $(\mathrm{P}<0.05)$. Hal ini diduga karena susut bobot telur yang lebih kecil memiliki kerabang telur yang lebih tebal dan jumlah pori-pori yang sedikit. Hasil uji statistik menunjukkan tidak adanya pengaruh perlakuan terhadap susut bobot telur tetas. Susut bobot telur dipengaruhi oleh faktor internal dan eksternal.

Faktor internal diantaranya adalah ketebalan kerabang dan kerapatan pori-pori kerabang. Septika et al. (2013) menjelaskan kerabang yang terlalu tebal menyebabkan telur kurang terpengaruh suhu penetasan sehingga penguapan air dan gas sangat kecil. Faktor eksternal meliputi suhu mesin tetas, kelembaban mesin tetas, dan lama penyimpanan sebelum telur dimasukan ke dalam mesin tetas. Suhu dan kelembaban mesin tetas adalah penyebab utama yang mempengaruhi susut tetas (Septika et al. 2013).

\section{Daya Tetas}

Daya tetas merupakan faktor utama dalam kegiatan penetasan. Daya tetas adalah persentase telur yang menetas dibandingkan dengan jumlah telur fertil. Hasil daya tetas telur itik alabio dalam penelitian ini disajikan pada Tabel 5. Tabel 5 menunjukkan telur itik yang diberikan perlakuan fumigasi (P1) menghasilkan daya tetas paling tinggi dibandingkan dengan daya tetas telur itik yang diberi perlakuan tanpa fumigasi dan tanpa sanitasi ekstrak pelepah pisang ambon (P0) dan perlakuan sanitasi dengan ekstrak pelepah pisang $10 \%(\mathrm{P} 2)$. Tabel tersebut juga menunjukkan bahwa daya tetas telur itik yang mendapat perlakuan perendaman dengan ekstrak pelepah pisang 10\% (P2) paling tinggi dibandingkan perlakuan perendaman ekstrak pelepah pisang 20\% (P3) dan 30\% (P4).

Semakin tinggi pengunaan ekstrak pelepah pisang, daya tetas telur semakin menurun. Hal ini diduga karena makin pekatnya ekstrak pelapah pisang, makin banyak pori-pori kerabang yang tertutup sehingga mengganggu proses metabolisme embrio. Menurut Alkhakim (2016), konsentrasi larutan yang terlalu pekat akan menutup poripori telur yang menyebabkan kebutuhan oksigen embrio tidak tercukupi. Selain itu, keefektifan bahan sanitasi juga dipengaruhi oleh kondisi kerabang telur itik yang tebal dan pori-pori yang sedikit.

\section{Kematian Embrio}

Kematian embrio menjadi salah satu faktor dalam mengevaluasi proses penetasan. Waktu kematian embrio dikelompokan menjadi 3 yaitu fase awal $(<8$ hari $)$, fase pertengahan (8-25 hari), dan fase akhir ( $>25$ hari). Persentase kematian embrio dalam penelitian ini disajikan dalam Gambar 1.

Waktu kematian embrio pada penelitian ini berbedabeda tiap perlakuan. Pada penelitian ini, ciri-ciri kematian embrio yang ditemukan pada masa awal inkubasi umumnya yaitu sudah terlihat adanya perkembangan germinal disc, terbentuknya blood ring, terbentuknya pembuluh darah, dan busuk. Ciri-ciri kematian embrio pada masa pertengahan inkubasi diantaranya adalah sudah terbentuk embrio sempurna, pendarahan, kerusakan organ, dan busuk.

Tabel 4. Susut bobot telur itik alabio

\begin{tabular}{|c|c|c|c|c|c|c|}
\hline \multirow[t]{3}{*}{ Keterangan } & \multicolumn{5}{|c|}{ Rataan \pm sb susut bobot $(K K ; n)$} & \multirow[t]{3}{*}{ Rataan $\pm \mathrm{sb}$} \\
\hline & $\mathrm{P} 0$ & P1 & $\mathrm{P} 2$ & P3 & P4 & \\
\hline & \multicolumn{5}{|c|}{$\%$} & \\
\hline Menetas & $\begin{array}{l}9.46 \pm 2.37 \\
(25.06 ; 53)\end{array}$ & $\begin{array}{l}9.83 \pm 2.27 \\
(23.13 ; 55)\end{array}$ & $\begin{array}{l}9.52 \pm 2.09 \\
(21.99 ; 50)\end{array}$ & $\begin{array}{l}9.40 \pm 2.27 \\
(24.17 ; 46)\end{array}$ & $\begin{array}{l}9.30 \pm 2.28 \\
(24.50 ; 45)\end{array}$ & $9.50 \pm 0.20 \mathrm{a}$ \\
\hline Tidak menetas & $\begin{array}{c}8.59 \pm 3.28 \\
(38.13 ; 6)\end{array}$ & $\begin{array}{c}8.54 \pm 2.78 \\
(32.57 ; 5)\end{array}$ & $\begin{array}{c}7.89 \pm 3.45 \\
(43.69 ; 9)\end{array}$ & $\begin{array}{c}8.22 \pm 1.33 \\
(16.22 ; 7)\end{array}$ & $\begin{array}{l}7.95 \pm 2.55 \\
(32.08 ; 16)\end{array}$ & $8.24 \pm 0.33 b$ \\
\hline
\end{tabular}


Tabel 5. Daya tetas telur itik alabio

\begin{tabular}{cccccc}
\hline \multirow{2}{*}{ Mesin } & \multicolumn{4}{c}{ Daya Tetas (\%) } \\
\cline { 2 - 6 } & P0 & P1 & P2 & P3 & P4 \\
\hline 1 & 68,18 & 63,16 & 57,89 & 77,78 & 23,53 \\
2 & 61,11 & 82,35 & 62,5 & 80 & 62,5 \\
3 & 71,43 & 78,95 & 94,12 & 41,18 & 65 \\
4 & 81,25 & 68,18 & 63,64 & 58,82 & 70 \\
\hline Rataan $\pm \mathrm{sb}$ & $70.49 \pm 8.37$ & $73.16 \pm 9.00$ & $69.54 \pm 16.57$ & $64.44 \pm 18.19$ & $55.26 \pm 21.38$ \\
\hline
\end{tabular}

Kematian embrio pada masa akhir inkubasi yang terlihat adalah embrio sudah terbentuk sempurna, kuning telur belum terserap sempurna, pendarahan, dan lemah.

Puncak kematian embrio pada inkubasi telur unggas biasanya terjadi pada tahap awal dan akhir inkubasi (Tullet 2009). Hal ini karena pada awal inkubasi, di dalam telur sedang terjadi pembentukan sistem organ, sedangkan pada akhir inkubasi terjadi proses perubahan sistem pernapasan ke paru-paru.

Tullet (2009) juga menyatakan kematian di awal inkubasi bisa disebabkan oleh kesalahan dalam penanganan telur tetas dan kontaminasi, sedangkan kematian pada pertengahan masa inkubasi bisa disebabkan karena kontaminasi, kekurangan nutrisi, dan ketidaksesuaian kondisi mesin tetas. Kematian embrio pada masa akhir inkubasi biasanya disebabkan karena ketidaksesuaian mesin tetas. Evaluasi kematian embrio diamati lebih lanjut untuk mengetahui jumlah telur yang terkontaminasi pada penelitian ini. Hasil evaluasi disajikan pada Gambar 2.

Gambar 2 menunjukkan persentase telur tertinggi yang mati akibat terkontaminasi mikroorganisme pada semua perlakuan terjadi di masa pertengahan inkubasi. Hal ini sesuai dengan pendapat Tullet (2009) bahwa kematian embrio pada masa pertengahan inkubasi kemungkinan besar disebabkan oleh kontaminasi dan kekurangan nutrisi. Jumlah telur terkontaminasi yang terendah adalah perlakuan $\mathrm{P} 2$, sedangkan telur jumlah telur terkontaminasi tertinggi adalah P0. Tingginya kontaminasi telur di P0 dapat disebabkan karena sanitasi dengan air hangat hanya mampu membersihkan kotoran tetapi belum efektif membunuh

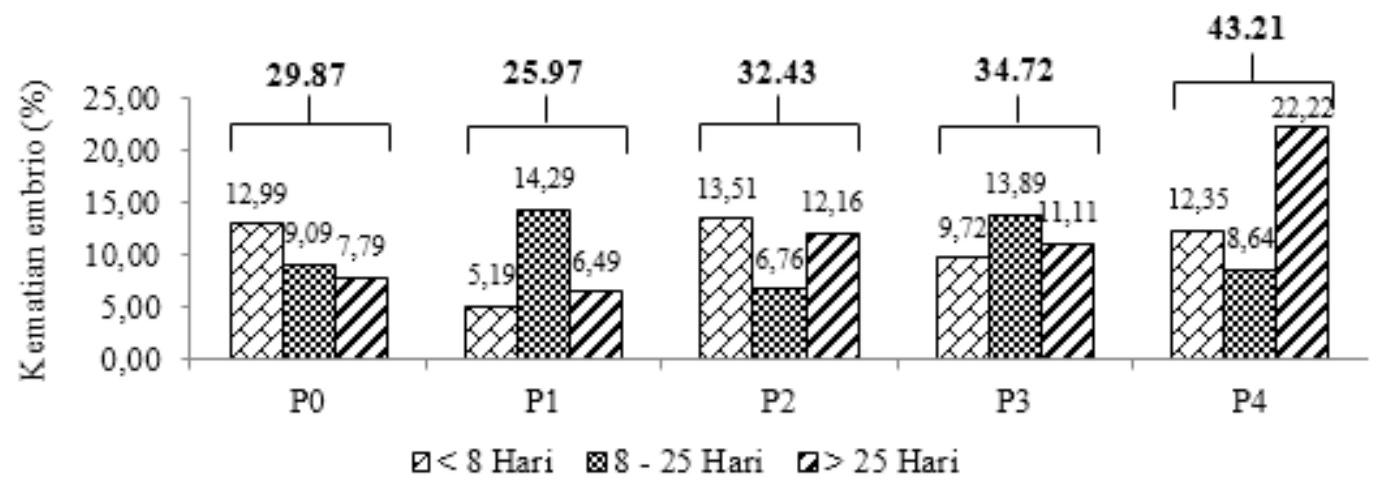

Gambar 1. Kematian embrio (\%) pada selang umur telur berbeda

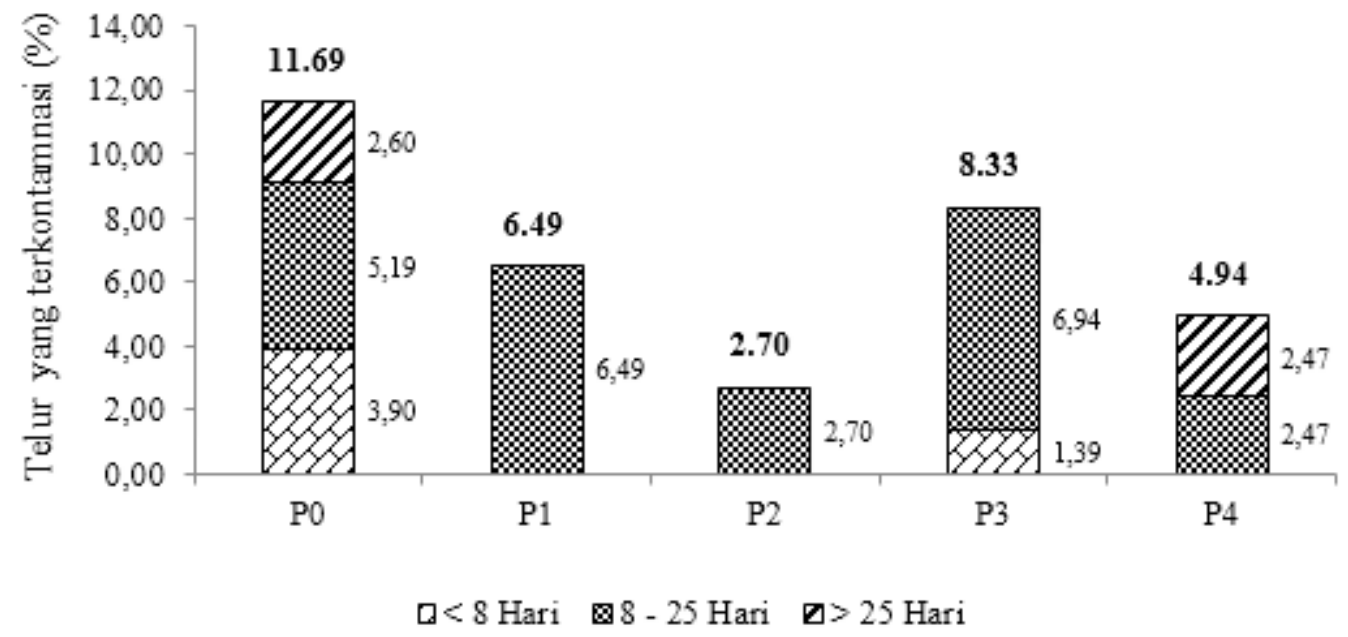

Gambar 2. Persentase telur yang terkontaminasi mikroorganisme 
bakteri. Telur yang terkontaminasi mikroorganisme pada penelitian ini memiliki ciri-ciri seperti berbau busuk, explode, kerusakan organ, dan isi telur menghitam.

Penelitian Parveen et al. (2017) menunjukkan bakteri yang ditemukan dalam kerabang telur diantaranya adalah Staphylococcus spp. (5.55\%), Escherichia coli (11.11\%), Salmonella serovars $(2.77 \%)$ and Bacillus spp. (8.33\%). Parveen et al. (2017) juga menambahkan kontaminasi bakteri dipengaruhi oleh beberapa faktor yaitu lingkungan pembibitan, praktik pemuliaan, sistem perkandangan, letak geografis, dan musim. Selain itu, kontaminasi juga dapat terjadi selama transportasi telur dan atau pengemasan di peternakan atau di tempat penyimpanan, baik melalui lingkungan atau dari satu telur ke telur lainnya.

Salah satu cara untuk menangani kontaminasi adalah dengan sanitasi kerabang telur menggunakan bahan yang bersifat antimikroba. Pisang (Musa paradisiaca) merupakan tanaman yang banyak dijumpai di Indonesia. Pemanfaatannya tidak hanya sebagai bahan pangan, tetapi juga sebagai bahan pengobatan. Beberapa penelitian telah dilakukan untuk mengetahui aktivitas antimikroba dari pohon pisang, mulai dari kulit sampai dengan batangnya.

Penelitian Nur et al. (2012) menyatakan penggunaan getah murni pelepah pisang ambon Musa paradisiaca var. Sapientum menunjukkan aktivitas antibakteri karena mampu menghambat pertumbuhan bakteri Staphylococcus aureus, Pseudomonas aeuroginosa dan Escherichia coli. Penelitian Fitrianingrum (2015) memberikan hasil pelepah pisang ambon memiliki kandungan fitokimia seperti flavonoid, alkaloid, triterpenoid, fenolik, saponin, tanin, steroid, dan glikosida. Mekanisme kerja flavonoid sebagai antibakteri adalah membentuk senyawa kompleks dengan protein ekstraseluler dan terlarut sehingga dapat merusak membran sel bakteri dan diikuti dengan keluarnya senyawa intraseluler (Cowan 1999; Nuria et al. 2009). Mekanisme kerja saponin sebagai antibakteri adalah menurunkan tegangan permukaan sehingga mengakibatkan naiknya permeabilitas atau kebocoran sel dan mengakibatkan senyawa intraseluler akan keluar (Nuria et al. 2009). Menurut Naiborhu (2002), tanin berperan sebagai pendenaturasi protein pada bakteri.

Mekanisme kerja fenol sebagai antibakteri yaitu dengan cara inaktivasi protein (enzim) pada membran sel. Fenol berikatan dengan protein melalui ikatan hidrogen sehingga mengakibatkan struktur protein menjadi rusak. Ketidakstabilan pada dinding sel dan membran sitoplasma bakteri menyebabkan fungsi permeabilitas selektif, fungsi pengangkutan aktif, pengendalian susunan protein dari sel bakteri menjadi terganggu, yang akan berakibat pada lolosnya makromolekul dan ion dari sel sehingga sel bakteri menjadi kehilangan bentuk dan lisis (Susanti 2008).

Telur yang disanitasi dengan ekstrak pelepah pisang lebih rendah dari telur yang diberi perlakuan fumigasi. Hal ini diduga disebabkan ekstrak pelepah pisang konsentrasi $10 \%, 20 \%$, dan 30\% masih terlalu pekat. Menurut Alkhakim (2016), konsentrasi larutan yang terlalu pekat akan menutup pori-pori telur yang menyebabkan kebutuhan oksigen embrio tidak tercukupi. Kandungan larutan yang dapat menutup pori-pori telur adalah tanin yang biasa digunakan sebagai bahan penyamak. Aripin (2013) menjelaskan reaksi penyamakan kerabang telur oleh tanin dapat menimbulkan koagulasi lapisan kutikula kulit telur yang tersusun dari protein. Kulit telur yang tersamak dapat berubah sifatnya ke arah impermiabel atau tidak bisa ditembus air dan gas.

\section{KESIMPULAN}

Ekstrak pelepah pisang dapat dimanfaatkan sebagai bahan sanitasi untuk meningkatkan daya tetas telur. Daya tetas telur itik yang disanitasi dengan ekstrak pelepah pisang $10 \%$ masih lebih rendah daripada daya tetas telur yang difumigasi. Semakin tinggi konsentrasi ekstrak pelepah pisang menyebabkan daya tetas telur semakin menurun. Untuk itu perlu dilakukan penelitian lebih lanjut menggunakan konsentrasi ekstrak pelepah pisang dengan konsentrasi yang lebih rendah dari 10\%.

\section{DAFTAR PUSTAKA}

[BPOM] Badan Pengawas Obat dan Makanan. 2008. Formalin (Larutan Formaldehida). Jakarta(ID): BPOM.

[BPOM] Badan Pengawas Obat dan Makanan. 2010. Acuan Sediaan Herbal .Volume 5 Edisi 1. Jakarta(ID): BPOM.

[BSN] Badan Standardisasi Nasional. 2009. Bibit Induk (Parent Stock) Itik Alabio MeriSNI 7557: 2009. Jakarta(ID): BSN.

[DPKH] Direktorat Jenderal Peternakan dan Kesehatan Hewan. 2017. Statistik Peternakan dan Kesehatan Hewan. Jakarta(ID): DPKH.

[Kementan] Kementerian Pertanian. 2016. Outlook Komoditas Pertanian Sub Sektir Hortikultura: Pisang. Jakarta (ID): Pusat Data dan Sistem Informasi Pertanian Kementerian Pertanian.

Alkhakim FH, Huda MN, Fitri GD, Ambarwati D, Tistiana H. 2016. Pengaruh ekstrak daun kersen terhadap daya tetas dan mortalitas telur itik hibrida. JIIP. 26(2): 8-13.

Ahyodi F, Nova K, Kurtini T. 2014. Pengaruh bobot telur terhadap fertilitas, susut tetas, daya tetas, dan bobot tetas telur kalkun. Jurnal Ilmiah Peternakan Terpadu. 2(1): 19-25.

Aripin CS. 2013. Pengaruh konsentrasi infusa daun sirih (Piper betle Linn.) pada pencelupan telur itik terhadap daya tetas dan kematian embrio.Journal of the Indonesian Tropical Animal Agriculture3(1).

Beleh FTM. 2008. Effect of various sanitizing treatments on hatchability of broiler breeder eggs [tesis]. Palestine (PS): An Najah National University.

Cowan MM. 1999. Plant products as antimicrobial agents. Clinil Microbiol Rev. 12(1): 564-582.

Darmawati D. 2013. Daya tetas telur itik cihateup dan alabio [skripsi]. Bogor (ID): Institut Pertanian Bogor.

Dewanti R, Yuhan, Sudiyono. 2014. Pengaruh bobot dan frekuensi pemutaran telur terhadap fertilitas, daya tetas, dan bobot tetas itik lokal. Buletin Peternakan 38(1): 16-20.

Diniati. 2013. Pengaruh waktu dimulainya pendinginan selama penetasan terhadap daya tetas telur itik persilangan cihateup alabio [skripsi]. Bogor (ID): 
Institut Pertanian Bogor.

Fitrianingrum IDN. 2015. Efektivitas ekstrak pelepah pisang sebagai antibakteri dan imunostimulan pada ikan gurame yang diinfeksi Aeromonas hydrophila[tesis]. Bogor (ID): Institut Pertanian Bogor.

Hanoun AME, Mossad NA. 2008. Hatchability improvement of pecking duck eggs by controlling water evaporation rate from the eggshell. Egypt Poultry Science 28(2): 767-784

Mahmudah FL, Atun S. 2017. Uji aktivitas antibakteri dari ekstrak etanol temukunci (Boesenbergia pandurata) terhadap bakteri Streptococcus mutans. Jurnal Penelitian Saintek 22(1): 59-66.

Murtidjo BA. 2005. Penetasan Itik dengan Menggunakan Sekam. Yogyakarta(ID): Kanisius.

Mulyantini NGA. 2010. Ilmu Manajemen Ternak Unggas. Yogyakarta(ID): Gadjah Mada University Pr.

Ningtyas MS. 2013. Pengaruh temperatur terhadap daya tetas dan hasil tetas itik (Anas plathyrinchos). Jurnal Ilmiah Peternakan. 1(1): 347-352.

Nur J, Dwyana Z, Abdullah A. 2012. Bioaktivitas pelepah pisang ambon Musa paradisiaca varsapientum terhadap pertumbuhan bakteri Staphylococcus aureus, Pseudomonas aeuroginosa dan Escherichia coli. Universitas Hasanudin.

Nuria MC, Faizatun A, Sumantri. 2009. Uji antibakteri ekstrak etanol daun jarak pagar (Jatropha cuircas L.) terhadapbakteri Staphylococcus aureus ATCC 25923, Escherichia coli ATCC 25922, dan Salmonella typhi ATCC 1408. Jurnal Ilmu - ilmu Pertanian 5: 26 - 37.
Onyema CT, Ofor CE, Okudo VC, Ogbuabu AS. 2016. Phytochemical and antimicrobial analysis of banana pseudostem (Musa acuminata). British Journal of Pharmaceutical Research 10(1): 1-9.

Parveen A, Rahman MM, Fakhruzzaman M, Akter MR, Islam MS. 2017. Characterization of bacterial pathogens from egg shell, egg yolk, feed, and air samples of poultry houses. Asian Journal of Medical and Biological Research 3(2): 168-174.

Sari ML, Noor RR, Hardjosworo PS, Nisa C. 2011. Keragaan telur tetas itik pegagan. J Sains Peternakan Indonesia6(2): 97-102.

Septika ER, Septinova D, Nova K. 2013. Pengaruh umur telur tetas persilangan itik tegal dan mojosari dengan penetasan kombinasi terhadap fertilitas dan daya tetas. Jurnal Ilmiah Peternakan Terpadu 1(3): 31-36.

Steel RGD, Torrie JH. 1995. Prinsip dan Prosedur Statistik Suatu Pendekatan Biometrik. (Principles and Procedures of Statistics). Terjemahan B. Sumantri) Cetakan ke-2. Jakarta(ID): PT. Gramedia.

Susanti DY. 2008. Efek suhu pengeringan terhadap kandungan fenolik dan kandungan katekin ekstrak daun kering Gambir. Jogjakarta (ID):Prosiding Seminar Nasional Teknik Pertanian.

Tullet S. 2009. Ross Tech Investigating Hatchery Practice. Alabama(US): Aviagen.

Zukhri S, Hidayati N. 2017. Aktivitas antimikroba ekstrak etanol pelepah pisang raja (Musa x paradisiaca $\mathrm{L}$ ) pada bakteri Staphylococcus aureus. GASTER. 15(2): 216231. 